\title{
UTICAJ TRUDNOĆE NA TOK I STEPEN KONTROLE ALERGIJSKE ASTME I RINITISA
}

\author{
INFLUENCE OF PREGNANCY ON FLOW AND LEVEL OF CONTROL ALLERGIC ASTHMA \\ AND RHINITIS
}

Natasa Tanasković, Biljana Zvezdin, Marinko Vučić, Tijana Kovačević, Ilija Baroš

\begin{abstract}
SAŽETAK : Incidenca akutnog pogoršanja astme u trudnoći je visoka, od 20 do $60 \%$ u zavisnosti od studija $i$ zemalja $u$ ko .Procenat teških pogoršanja astme u trudnoći koje zahtevaju hospitalno lečenje se kreće se od 10 do $40 \%$, u zavisnosti od stepena težine $i$ kontrole astme pre trudnoće. Faktori rizika pojave akutnog pogoršanja astme tokom trudnoće su brojni . Na prvom mestu su virusne infekcije $i$ prestanak uzimanja lekova. Optimalni tretman je od ključne važnosti. $U$ radu su prikazana iskustva sa trudnicama koje boluju od alergijske astme, čiji tok bolesti je praćen od dana javljanja na pregled do porođaja. Rađena je retrospektivno-prospektivna ", pilot studija“. Istraživanjem je obuhvaćeno i praćeno od ukupnog broja pregledanih žena asmatičara (325) 20 trudnica, koje su pregledane u Klinici za plućne bolesti, UKC RS, u periodu od januara 2012 do kraja 2014 godine. Kod pacijentkinja je praćena: starost, gestacijska sedmica u kojoj su se javile na pregled, pušačke navike, potvrda alergije "prick" testom, vrsta alergijske bolesti, kontinuitet terapije, tok bolesti, pridružene bolesti, vrsta i doza lekova, broj porođaja, tok trudnoće.
\end{abstract}

Ključne reči: astma, trudnoća.

\section{UVOD}

Incidenca akutnog pogoršanja astme u trudnoći je visoka, od 20 do $60 \%$ u zavisnosti od studija i zemalja u kojima su rađene .Procenat teških pogoršanja astme $u$ trudnoći koje zahtevaju hospitalno lečenje se kreće se od 10 do $40 \%$, u zavisnosti od stepena težine i kontrole astme pre trudnoće . Faktori rizika pojave akutnog pogoršanja astme tokom trudnoće su brojni . Na prvom mestu su virusne infekcije i prestanak uzimanja lekova. U jednoj od dostupnh studija , obzirom na jako mali broj studija na trudnicama, $\mathrm{u}$ $59 \%$ slučajeva uzrok akutnog pogoršanja astme u trudnoći bila virusna infekcija, dok je $27 \%$ trudnica prijavilo da su prestale da uzimaju terapiju za astmu čim su saznale da su trudne. $\mathrm{Na}$ pogoršanje simptoma astme $\mathrm{u}$ trudnoći, pored hormonskih promena, utiču i izmenjeni imuni mehanizmi, aktivacije leukocitnih subpopulacija, smanjen celularni imuni odgovor. Postoji podaci da majčin imuni sistem tokom trudnoće postaje " prijemčiiviji , za virusne infekcije [1].
Hormonske i anatomske promene, krajem drugog i početkom trećeg trimestra trudnoće ,izmedju 24 i 34 gestacijske nedelje .

Povećana incidenca komplikacija astme uočena je kod trudnica koje nose ženski plod, 50\% trudnica koje su rodile žensku decu imalo pogoršane simptome astme $u$ trudnoći, $u$ odnosu na $22 \%$ trudnica koje su rodile dečake, a da je čak $44 \%$ majki dečaka prijavilo poboljšanje simptoma astme tokom trudnoće. [2]

Postojeći simptomi astme se mogu pogoršati, poboljšati ili ostati nepromenjeni za vreme trudnoće, takozvano „p pravilo trećine“.Optimalni tretman je od ključne važnosti. Rizik od preeklampsije, prevremenog poroda, niske porođajne težine, majčine i neonatalne hipoksije , morbiditeta koji mogu biti posledica nelečene astme često je veći od upotrebe bilo kog leka za lečenje astme.

\section{MATERIJAL I METODE}

U radu su prikazana iskustva sa trudnicama koje boluju od alergijske astme, čiji tok bolesti je 
praćen od dana javljanja na pregled do porođaja. Rađena je retrospektivno-prospektivna „pilot studija“. Istraživanjem je obuhvaćeno i praćeno od ukupnog broja žena asmatičara ( 325) 20 trudnica, koje su pregledane u Klinici za plućne bolesti ,Univerzitetskog Kliničkog Centra Republike Srpske u periodu od januara 2012 do kraja 2014 godine.

Trudnice su ambulantno praćene a anamnestički podaci prikupljeni tokom pregleda $\mathrm{i}$ iz istorija bolesti. Kod pacijentkinja je praćena: starost, gestacijska sedmica u kojoj su se javile na pregled, pušačke navike, potvrda alergije "prick" testom, vrsta alergijske bolesti, kontinuitet terapije, tok bolesti, pridružene bolesti, vrsta i doza lekova, broj porođaja, tok trudnoće. Telefonskim kontaktom dobijeni su podaci o ishodu trudnoće $\mathrm{i}$ načinu porođaja (vaginalno ili carskim rezom).

\section{REZULTATI}

\subsection{Starosna dob ispitanica}

U odnosu na starosnu dob, najmlađa pacijentkinja je imala 19 godina, a najstarija 41 godinu, tako da je prosječna starost u uzorku 31,05 godina. (Grafikon 1)

\section{STAROST PACIJENTKINJA}

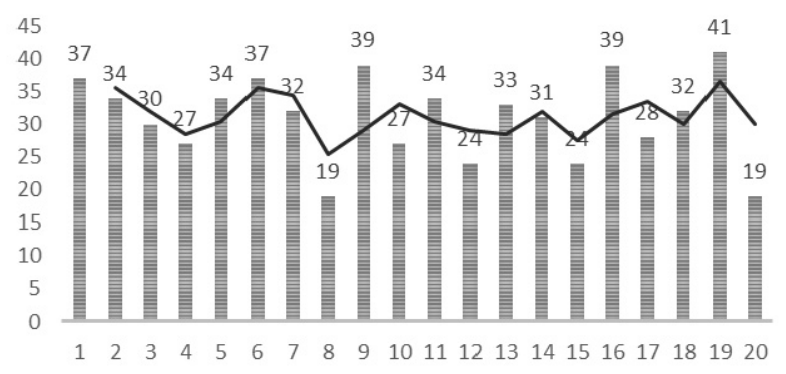

Grafikon 1 - Starosna dob ispitanica

\subsection{Prethodne trudnoće}

U ispitivanoj populaciji (20), 13 (65\%) pacijentkinja su prvorotoke a ostalih sedam ( $35 \%$ ) su drugorotke i trećerotke (Grafikon 2)

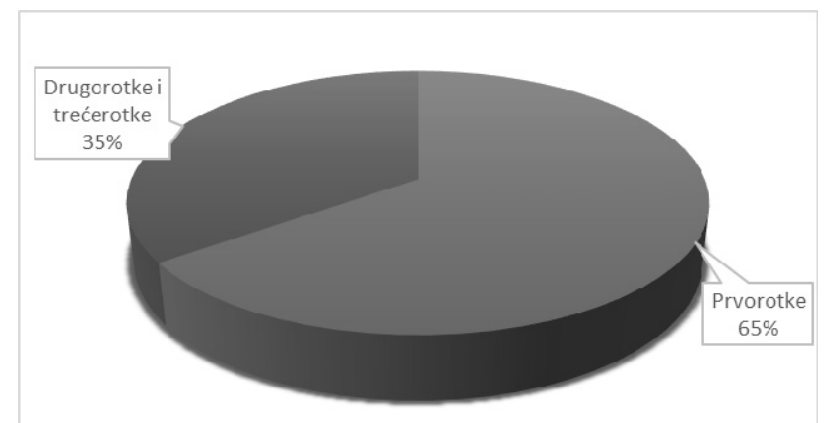

Grafikon 2 -Broj prethodnih trudnoća

\subsection{Zastupljenost pušačkih navika}

U ispitivanoj populaciji (20), devet (45\%) žena su pušači i bivši pušači a njih $11(55 \%)$ su nepušači. ( Grafikon 3)

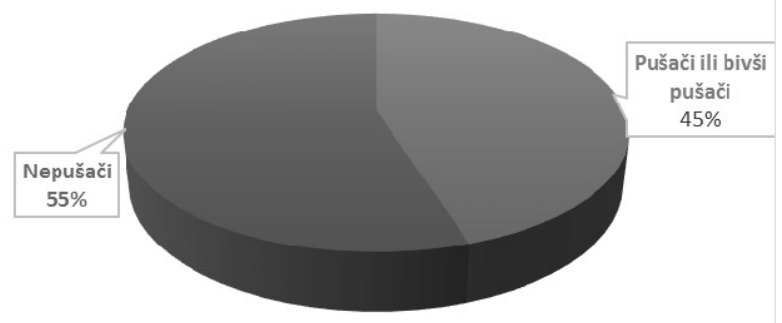

Grafikon 3 - Zastupljenost pušačkih navika

\subsection{Vreme javljanja na prvi pregled}

U ispitivanoj populaciji (20), u prvom trimestru se javio $14(70 \%)$ pacijentkinja a šest žena (30\%) u posljednjem trisemestru. ( Grafikon 4)

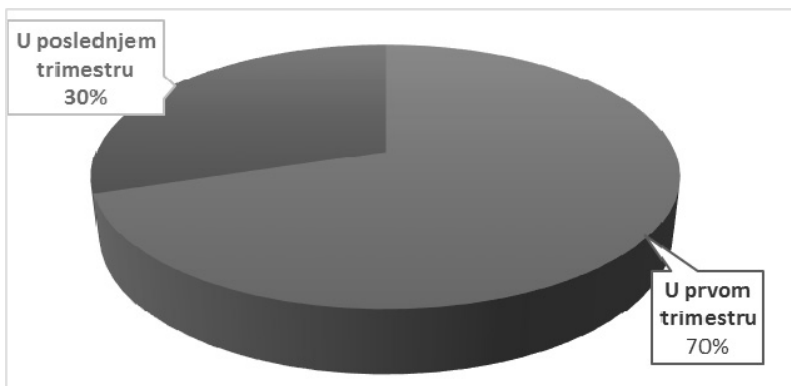

Grafikon 4 - Vreme javljanja na prvi pregled 


\subsection{Vrsta i udruženost alergijskih bolesti}

U ispitivanoj populaciji (20), 11 pacijentkinja je imalo astmu i pridruženi rinitis, jedna je imala astmu i pridruženi rinitis $i$ angioedem, dve pacijentkinje su imale astmu, pridruženi rinitis $i$ atopijski dermatitis. Nijedna pacijentkinja nije imala astmu bez pridruženog rinitisa.

Udruženi rinosinusitis i konjuktivitis su imale četiri pacijentkinje, rinosinusitis i urtikariju je imala jedna, a rinosinusitis i nutritivnu alergiju jedna pacijentkinja . Astme bez pridruženog rinitisa nije bilo u ispitivanoj grupi. (Tabela 1)

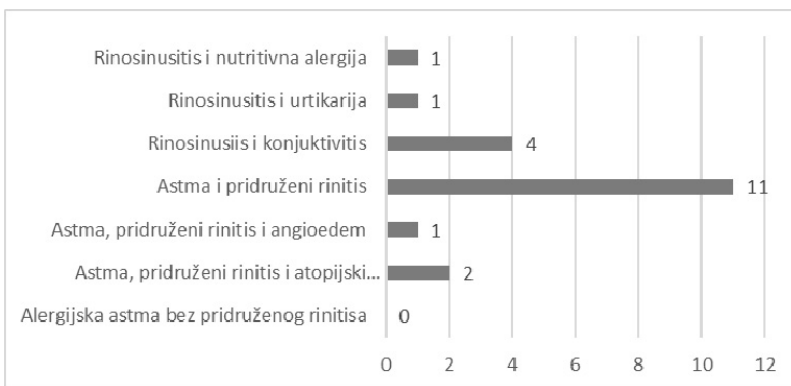

Tabela 1 - Vrsta i udruženost alergijskih bolesti

\subsection{Potvrda alergije "PRICK testom}

U ispitivanoj populaciji (20), kod 17 (85\%) pacijentkinja, pre trudnoće, je dokazana alergija pozitivnim PRICK testom, a kod tri (15\%) test nije rađen test. ( Grafikon 7) .Testiranje tokom trudnoće nije rađeno.

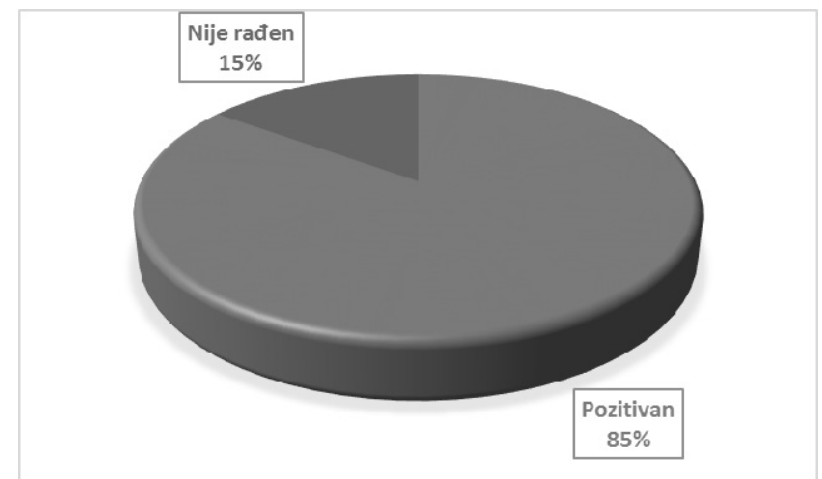

Grafikon 7-Potvrda alergije „PRICK“ testom

\subsection{Tretman astme pre trudnoće}

$\mathrm{U}$ ispitivanoj populaciji (20), 14 pacijentkinja je imalo ranije dijagnostikovanu astmu. Njih osam $(57 \%)$ je redovno uzimalo terapiju a šest pacijentkinja $(47 \%)$ je prekinulo terapiju odmah po saznanju da su u drugom stanju, od toga njih tri su bile bez terapije više od godinu dana. (Grafikon 6)

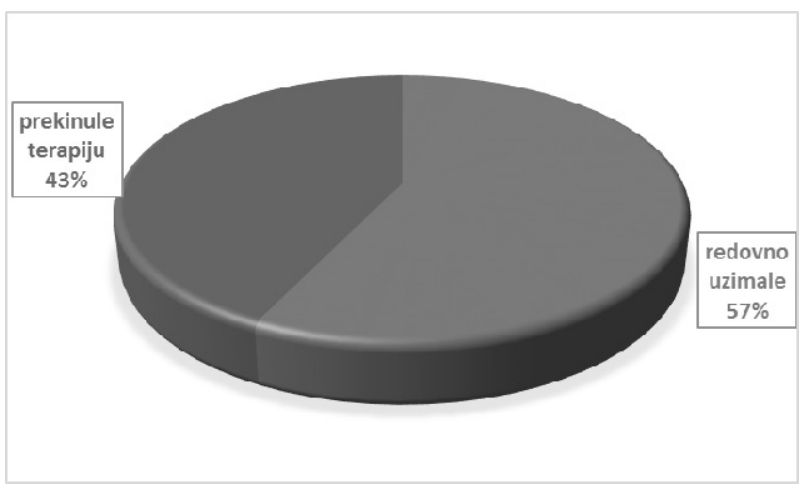

Grafikon 6 - Tretman astme pre trudnoće

\subsection{Tretman astme tokom trudnoće}

Tokom ispitivanja (20), svih 14 pacijentkinja je bilo pod terapijom, njih osam je uzimalo redovno terapiju, kod ostalih šest je uvedena odmah nakon pregleda i procene.

Sedam pacijentkinja je bilo na monoterapiji ICS , od toga njih pet je koristilo budesonid / niske do srednje doze/, jedna - ciklesonid /niska doza/, jedna - flutikazon furoat /srednja doza/. Ventolin po potrebi je koristila samo jedna pacijentkinja. Kombinovanu terapiju ICS / LABA je uzimalo šest pacijentkinja, od toga dve budesonidformoterol / srednje doze/, dve - budesonidformoterol /visoke doze/, jedna - fluticasonsalmeterol /srednja doza/, jedna - beclomethason formoterol -srednja doza . (Tabela 2)

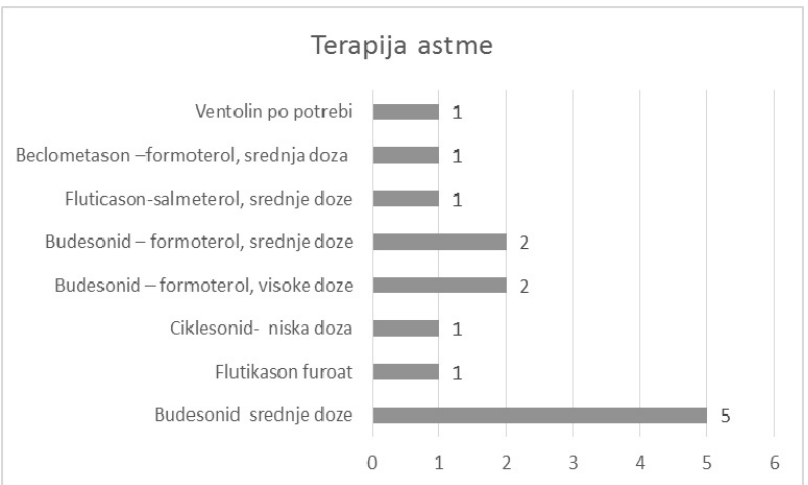

Tabela 2 - Tretman astme tokom trudnoće 


\subsection{Vrsta i učestalost pridruženih bolesti}

$\mathrm{U}$ ispitivanoj populaciji (20), 11 pacijentkinja je imalo pridružene bolesti, od toga šest pacijentkinja je imalo GERB, dve virusnu infekciju a po jedna ispitanica je imala preeklampsiju, trombofiliju i bakterijsku infekciju. ( Tabela 3)

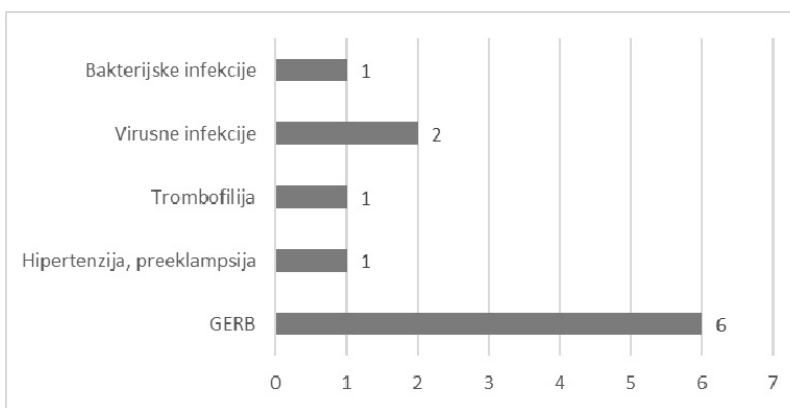

Tabela 3-Vrsta i učestalost pridruženih bolesti

\subsection{Primena intranazalnog kortikosteroida}

U ispitivanoj populaciji (20), sve pacijentkinje su male rinitis, sam ili udružen sa astmom ili nekom drugom alergijskom bolešću. Njih 14 (70\%) je tokom sezonskih pogoršanja, uz ostalu nefarmakološku terapiju koristilo mometason furoat, a šest (30\%) fluticason u punoj terapijskoj dozi ( Grafikom 5.) Antihistamici su korišteni sporadično i po potrebi kod $10 \%$ ispitanica (loratadin).

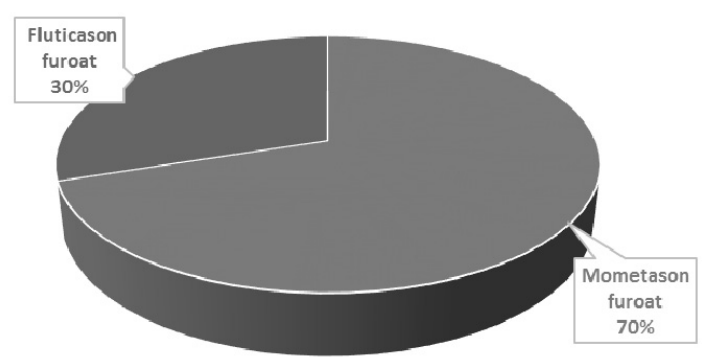

Grafikon 5 - Primena intranazalnog kortikosteroida

\subsection{Procena spirometrijskog nalaza}

U ispitivanoj populaciji (20), $15 \quad(75 \%)$ pacijentkinja je tokom perioda praćenja imalo plućnu funkciju u referentnim vrednostima iznad $100 \%$, ( FVC, FEV1, FVC/ FEV1) a kod pet trudnica $(25 \%)$ je registrovan opstruktivni poremećaj ventilacije ( Grafikon 8 )

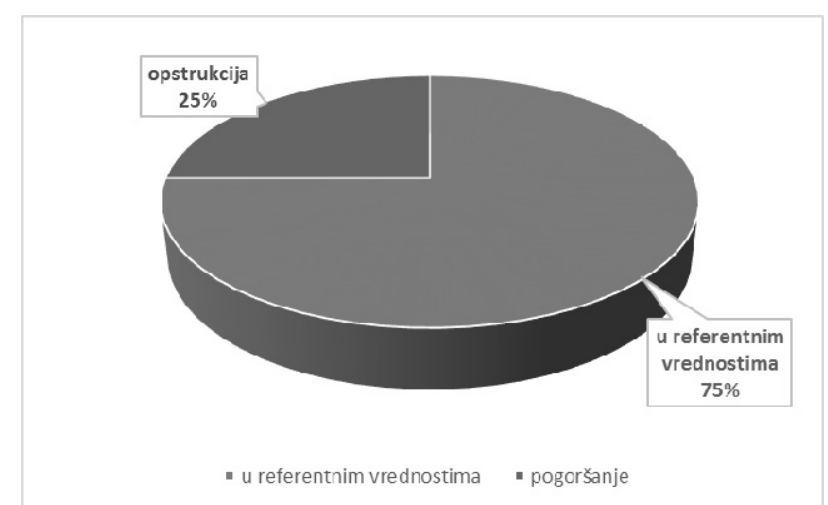

Grafikon 8 - Procena spirometrijskog nalaza

\subsection{Procena saturacije kiseonikom}

$\mathrm{U}$ ispitivanoj populaciji (20), kod 18 pacijentkinja (90\%) saturacija kiseonikom je bila zadovoljavajuća (96-98\%) a kod dve (10\%) je bila ispod 90\%. ( Grafikon 9)

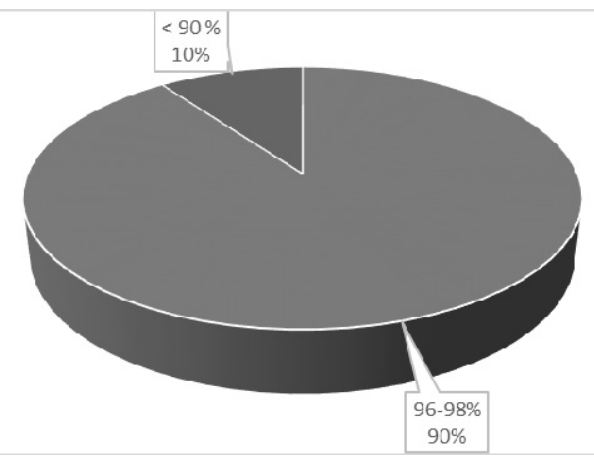

Grafikon 9 - Procena saturacije kiseonikom

\subsection{Procena kontrole astme tokom trudnoće}

U ispitivanoj populaciji (20), $15 \quad$ (75\%) pacijentkinja je imalo tok bolesti bez komplikacija a njih pet $(25 \%)$ je imalo pogoršanje ( astma udružena sa rinitisom ), od toga dve trudnice su bile hospitalizovane. (Grafikon 10).

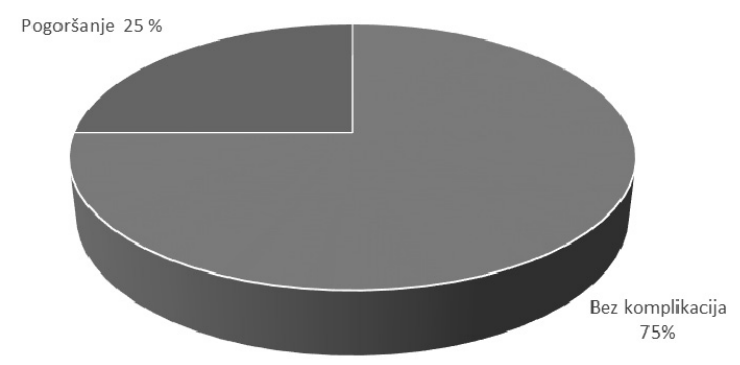


Grafikon 10 - Procena kontrole astme tokom trudnoće

\section{DISKUSIJA}

Tokom ispitivanja uočeno je da je tok trudnoće kod svih ispitanica protekao uredno, porođaj $\mathrm{u}$ terminu , normalnim putem kod njih 13, carskim rezom kod sedam žena. Rođeno je 11 dečaka i 9 devojčica. U prvom trimestru trudnoće na pregled se javilo $70 \%$ trudnica , razlozi javljanja su najčešće bili potreba za savetom o terapiji. U poslednjem trimestru $30 \%$ razlozi javljanja su bili neregulisani simptomi, pogoršanje bolesti i insistiranje ginekologa.

Tok i ishod trudnoće u ovom istraživanju bio je zadovoljavajući u svim slučajevima, bebe su bile zdrave na porodjaju. Medju rođenim bebama preovladavao je muški pol $(65 \%)$.

Od ukupnog broja ispitanica njih 14 je imalo potvrđenu bronhijalnu astmu pre trudnoće ( umerenu perzistentnu udruženu sa rinitisom), od toga njih osam je redovno koristilo terapiju i imalo dobru kontrolu simptoma na niskim i srednjim dozama ICS. Preostalih šest je uzimalo terapiju povremeno, tri pacijentknje su prekinule od momenta saznanja da su u drugom stanju, ostalih tri je bilo bez terapije više od godinu dana

U grupi koja je imala pogoršanje , od ukupno njih pet razlog akutnog pogoršanja je bilo duži period bez terapije kod dve , respiratorna infekcija kod dve a bakterijska infekcija kod jedne ispitanice

Dve hospitalizovane trudnice su imale pri prijemu karakteristike teškog pogoršanja astme, na osnovu kliničkih i objektivnih kriterijuma, jedna pacijentkinja je hospitalizovana u jedinici intezivne nege zbog preeklampsije i neregulisane hipertenzije udružene sa teškim napadom astme. Obe bolesnice su iz grupe koja nije uzimala terapiju ICS duže od godinu dana. Pogoršanja kod ostalih pacijentkinja su tretirana ambulantno, uz adekvatno povećanje doze leka do postizanja kontrole simptoma.

Najčešći simptomi pogoršanja su bili otežano disanje i vizing (kod svih), kašalj, bez povišene telesne temperature. Ovim simptomima kod svih slučajeva su prethodili simptomi gornjih disajnih puteva u smislu kongestije nosne sluznice i pojačane nosne sekrecije, od par dana do nekoliko nedelja. Pogoršanje parametara plućne funkcije je uočeno kod svih pet, a pad saturacije kod dve bolesnice, parcijalna respiratorna insuficijencija sa normokapnijom što u trudnoći predstavlja visok rizik po majku i bebu.

U krvnoj slici jedna bolesnica je imalo leukocitozu i povišene markere inflamacije, komplikaciju po tipu bakterijske bronhopneumonije koja je potvrđena laboratorijski i klinički, RTG pluća nije rađen. Alergijski rinitis se pogoršavao sezonski, nevezano za period trudnoće ,angioedem, urtikarija i AD su bili neporomenjenog toka $\mathrm{u}$ odnosu na period pre trudnoće. Komplikacija sa pacijentkinjom koja ima nutritivnu alergiju nije bilo.

Od pridruženih bolesti najčešči je GERB koji je bio tretiran nefarmakološki ( ishrana, položaj ) samo dve trudnice su uzimale antacide i blokatore protonske pumpe sporadično i po potrebi. Iako se radi o malom broju ispitanika nije uočena značajna veza izmedju dobi trudnica, pariteta, pušačkih navika i pojave teškog pogoršanja astme u trudnoći.

\section{ZAKLJUČAK}

Strah “ od lekova " i prestanak uzimanja lekova u trudnoći predstavlja veliki problem. Zahteva edukaciju i informisanost o bezbednosti farmakoterapije i potencijalnim rizicima koje nosi težak napad astme, kako za majku tako i za plod. Rezultati u našem radu su u skladu sa takvim stavom. Pravilno lečene i kontrolisane trudnice su imale povoljan tok bolesti, bez značajnih pogoršanja.

Klinički simptomi i znaci akutnog pogoršanja astme u trudnoći ne razlikuju se u odnosu na ostalu populaciju asmatičara. Uglavnom se radi o ženama koje već imaju dijagnostikovanu alergijsku astmu, više godina pre trudnoće. Ukoliko se simptomi i znaci astme jave bez prethodne istorije bolesti, dijagnoza se postavlja na osnovu nalaza plućne funkcije i bronhodilatatornog testa (povećanje FEV1 za više od 12\%). Nije indikovano raditi bronhoprovokativne testove $\mathrm{u}$ toku trudnoće, kao ni alergijske kutane probe. Oko $2 / 3$ trudnica ima dispnoične tegobe u trudnoći koje mogu biti različitog uzroka, nevezano za astmu.

Lečenje akutnog napada astme tokom trudnoće ne razlikuje se bitno od preporuka za lečenje ostalih pacijenata: ponavljane inhalacije beta 2 
agonistima, kiseonik i kortikosteroidi (oralno ili parenteralno). Takođe se preporučuje dodati nebulizaciju ipratropium bromida kod bolesnica koje ne daju povoljan odgovor na inhalacije beta agonista.

Ciljevi lečenja astme u trudnoći su isti kao i oni za astmu u celini: proceniti, lečiti, pratiti. To uključuje i prevenciju teških egzacerbacija, poboljšanje kvaliteta života (bez noćnog buđenja ili ometanja dnevnih aktivnosti) i održavanje normalne plućne funkcije. Preporuke za lečenje sažete su i navedene u priručniku Globalne Inicijative za Astmu (GINA) koji se redovno revidira u skladu sa kategorijama dokaza i služi kao terapijsko-dijagnostički vodič u većini evropskih zemalja.

U skladu sa preporukama za tretman astme $u$ trudnoći, izdvojeni su pojedini lekovi:

- Ipratropijum bromid, kratko delujući antiholinergik (nivo preporuke B), Budesonid-inhalatorni kortikosterioid sa najvišim nivoom preporuke $u$ smislu sigurnosti, $u$ odnosu na druge ICS ( nivo preporuke B), Salmeterol i formoterol, dugo delujući beta 2-agonisti, su dodatna terapija, uvek u kombinaciji sa ICS, kod trudnica sa nekontrolisanom perzistentnom astmom ( nivo preporuke C), Leukotrijenski modifikatori (montelukast i zafirlukast), mogu se koristiti kao alternativni dodatak, ali samo kod trudnica kod kojih su dovodili do kontrole astme pre nastanka trudnoće nivo preporuke B)

Salbutamol, kratko delujući beta 2-agonista, najčešće primenjivani lek za brzo smanjenje tegoba, iako je nivoa preporuke $\mathrm{C}$, smatra se sigurnim zbog najduže primene (od sredine prošlog veka), Zileuton, inhibitor sinteze leukotrijena se ne preporučuje u trudnoći, zbog njegovog potencijala da izazove abnormalne funkcije jetre ( kategorija C).

Pacijentkinje čija astma nije pod kontrolom i pored maksimalnih doza bronhodilatatora i ICS-a moraju se tretirati sistemskim kortikosteroidima (prednizon i prednizolon, nivo preporuke B i C). Treba naći najmanju moguću efikasnu dozu. Trudnicu i bebu treba pažljivo pratiti zbog mogućih negativnih efekata kortikosteroida (posebno gestacijski dijabetes, preeklampsija i intrauterini zastoj rasta). Saradnja pulmologa i ginekologa mora biti kontinuirana tokom čitave trudnoće.

Jedna od novijih, mogućih, opcija tretmana teške alergijske astme (GINA, terapijski korak 5) je primena rekombinantnih DNK-izvedenih humanizovanih monoklonskih antitela, omalizumaba, koji se veže za specifični imunoglobulin E u krvi. Trenutno je od strane FDA svrstan u B kategoriju, na osnovu ohrabrujućih istraživanja na životinjama i ograničenog prolaska kroz posteljicu u prvom trimestru zbog veličine molekula. U toku je meta analiza registra od 250 žena tretiranih omalizumab-om tokom trudnoće, te se $u$ budućnosti mogu očekivati novi zaključci u vezi sa ovakvim tretmanom [10]. Intravenski aminofilin se generalno ne preporučuje (zbog potencijalno štetnih efekata), ali se može davati kod trudnica koje su hospitalizovane zbog akutnog napada (koncentracija teofilina u krvi se mora pratiti). Intravenski magnezijum sulfat može biti od koristi u akutnom napadu teške astme kao dodatak inhalacijama beta 2 agonistima i kortikosteroidima.

Optimalna kontrola astme tokom trudnoće podrazumeva monitoring plućne funkcije, saturacije kisenikom, izbegavanje takozvanih „okidača“ edukaciju pacijentkinja, preporuku i redovnu primenu adekvatne farmakoterapije. ", Korak na dole " u terapiji podrazumeva smanjenje terapije do najmanje efektivne doze leka potrebnog za kontrolu astme, zasnovan je na preporukama za odredjeni stepen astme, pažljivoj kliničkoj proceni, i ne razlikuje se bitno od ostalih pacijenata Akutno pogoršanje astme $u$ trudnoći treba lečiti pravovremeno i agresivno. Glavni cilj terapije jeste prevencija hipoksičnih epizoda majke i održanje adekvatne fetalne oksigenacije.

Pad saturacije O2 u krvi majke ispod $90 \%$ i $\mathrm{PaO} 2$ ispod $8 \mathrm{kPa}$ može dovesti do fetalne hipoksije. Terapija akutnog pogoršanja astme $u$ trudnoći se sprovodi prema preporukama NAEPP, nacionalnog programa za edukaciju i prevenciju astme ( engl. National Asthma Education and Prevention Program), koje se periodično revidiraju u skladu sa nivoom dokaza.

Aktuelne svetske smernice preporučuju i naglašavaju važnost edukacije, davanje saveta o astmi, pregled pre začeća, redovno kontrolisanje svake četiri sedmice, obavezan individualni 
akcioni plan lečenja, identifikaciju i tretman komorbiditeta. Krajnji i najvažniji cilj je bezbednost majke i rođenje zdravog potomka.

\section{LITERATURA}

1. Apter AJ. Advances in the care of adults with asthma and allergy in 2007. J Allergy Clin Immunol.2008;121:839-44. [PubMed]

2. Bakhireva LN, Schatz M, Jones KL, Tucker CM, Slymen DJ, Klonoff-Cohen HS, Gresham L, Johnson D, Chambers CD. OTIS Collaborative Research Group. Fetal sex and maternal asthma control in pregnancy. J Asthma. 2008;45:403-407. doi:

10.1080/02770900801971826. [PubMed][Cross Ref]

3. Simons FE, Schatz M. Anaphylaxis during pregnancy. The Journal of allergy and clinical immunology. doi:10.1016/j.jaci.2012.06.03

4. Cox L, Nelson H, Lockey R, Calabria C, Chacko T, Finegold I et al. Allergen immunotherapy: a practice parameter third update. The Journal of allergy and clinical immunology. 2011;127(1 Suppl):S1-55. doi:10.1016/j.jaci.2010.09.0. Lieberman J. Should we encourage allergen immunotherapy during pregnancy? Expert review of clinical immunology. 2014;10(3):317-9. doi:10.1586/1744666X.2014.881718
5. Namazy JA, Schatz M. Pharmacotherapy options to treat asthma during pregnancy. Expert opinion on pharmacotherapy. 2015;16(12):1783-91. doi:10.1517/14656566.2015.1066332.

6. Triche EW, Saftlas AF, Belanger K, Leaderer BP, Bracken MB. Association of asthma diagnosis, severity, symptoms, and treatment with risk of preeclampsia. Obstetrics and gynecology. 2004;104(3):585-93. doi:10.1097/01.AOG.0000136481.05983.91.

7. . Namazy JA, Schatz M. Asthma and rhinitis during pregnancy. The Mount Sinai journal of medicine, New York. 2011;78(5):661-70. doi: $10.1002 / \mathrm{msj} .20284$.

9. Odedra KM. Treatment of rhinitis in pregnancy. Nurs Stand. 2014;29(8):37-41. doi:10.7748/ns.29.8.37.e9089.

8. Lione A, Scialli AR. The developmental toxicity of the H1 histamine antagonists. Reprod Toxicol. 1996;10(4):247-55.

9. Pali-Scholl I, Renz H, Jensen-Jarolim E. Update on allergies in pregnancy, lactation, and early childhood. The Journal of allergy and clinical immunology. 2009;123(5):1012-21. doi:10.1016/j.jaci.2009.01.045.

10. Namazy J, Cabana MD, Scheuerle AE, Thorp JM, Jr., Chen $H$, Carrigan $G$ et al. The Xolair Pregnancy Registry (EXPECT): the safety of omalizumab use during pregnancy. The Journal of allergy and clinical immunology. 2015;135(2):40712.

SUMMARY: Incidence of acute exacerbations during pregnancy is high, from 20 to $60 \%$ depending on the study and in countries who .Procenat severe asthma exacerbations during pregnancy that require hospital treatment ranges from 10 to $40 \%$, depending on the severity and control asthma before pregnancy. Risk factors for the onset of acute asthma exacerbations during pregnancy are numerous. In the first place viral infection and stop taking drugs. Optimal treatment is crucial. The paper presents experience with pregnant women who suffer from allergic asthma whose disease course was followed from the date of reporting for approval before delivery. It is made retrospective-prospective "pilot study". The study included and followed by the total number of examined women asthmatics (325) 20 pregnant women were examined at the Department of Pulmonary Diseases, University Medical Center of the RS, in the period from January 2012 to the end of 2014. When the patient is monitored: age, gestational week in which they answered the inspection, smoking habits, confirmation allergy "prick" test, a kind of allergic diseases, the continuity of therapy, the disease, comorbidities, type and dose of drugs, the number of birth, current pregnancy.

Key words: asthma, pregnancy 
Kinika za plućne bolesti, UKC RS , Banja Luka

E-mail :maxpulm@yahoo.com 